\title{
Retention capacity of maltodextrin antioxidants in cranberry juice by spray drying process
}

\section{Capacidad de retención de antioxidantes de maltodextrina en jugo de arándano en polvo secado por aspersión}

SAAVEDRA-LEOS, María Zenaida†*, SILVA-CÁZARES, Macrina Beatriz, GONZÁLEZ-TREVIZO, Cynthia Lizeth and TERRONES-GURROLA, María Cruz del Rocío

Universidad Autónoma de San Luis Potosí

ID $1^{\text {st }}$ Author: María Zenaida, Saavedra-Leos / ORC ID: 0000-0001-6721-7114, CVU CONACYT ID: 207550

ID $1^{\text {st }}$ Coauthor: Macrina Beatriz, Silva-Cázares / ORC ID: 0000-0002-0277-0186, CVU CONACYT ID: 253090

ID $2^{\text {nd }}$ Coauthor: Cynthia Lizeth, González-Trevizo / ORC ID: 0000-0002-2720-7242, CVU CONACYT ID: 252863

ID $3^{\text {rd }}$ Coauthor: María Cruz del Rocío, Terrones-Gurrola / ORC ID: 0000-0002-2165-4674, CVU CONACYT ID: 448978

\begin{abstract}
A group of four maltodextrins with different degrees of dextrose equivalent (DE) was used as carriers for the spray drying of cranberry juice, with the objective of evaluating the effect of drying temperature, DE grade and concentration of maltodextrin on the performance of cranberry juice powder and the ability to retain antioxidants. For this purpose, the conditions of the spray drying process were: inlet air temperature: $170-210^{\circ} \mathrm{C}$, maltodextrin type (Mc, M10, M20 and M40) and maltodextrin concentration: $10-30 \% \mathrm{w} / \mathrm{w}$. The different powders obtained from the spray drying process were analyzed by high performance liquid chromatography (HPLC) for the quantification of antioxidants (resveratrol and quercetin). The analysis of the data was carried out from a design of D-Optimal experiments. The results of the analysis showed that the highest yield of cranberry juice powder is achieved by using $30 \% \mathrm{w} / \mathrm{w}$ of M10 at a drying temperature of $193{ }^{\circ} \mathrm{C}$. Such conditions allowed a retention of antioxidants in the powder of $20 \%$ and $30 \%$ of resveratrol and quercetin, respectively.
\end{abstract}

Antioxidants, Cranberry, Spray drying process

\section{Resumen}

Un grupo de cuatro maltodextrinas fueron utilizadas como agentes acarreadores para el secado por aspersión de jugo de arándano, con el objetivo de evaluar el efecto de la temperatura de secado y la concentración de maltodextrina sobre el rendimiento de jugo de arándano en polvo y la capacidad de retención de antioxidantes. Para tal efecto las condiciones del proceso de secado por aspersión fueron: temperatura de aire de entrada: $170-210^{\circ} \mathrm{C}$ y concentración de maltodextrina: $10-30 \%$ p/p. Los diferentes polvos obtenidos del secado por aspersión, fueron analizados mediante cromatografía líquida de alta resolución (HPLC) para la cuantificación de dos antioxidantes. El análisis de los datos se llevó a cabo a partir de un diseño de experimentos D-Optimo. Los resultados del análisis realizado mostraron que el mayor rendimiento de jugo de arándano en polvo se logra al utilizar 30\% p/p de M10 a una temperatura de secado de $193{ }^{\circ} \mathrm{C}$.

Antioxidantes, Arándano, Polvo secado por aspersión

Citation: SAAVEDRA-LEOS, María Zenaida, SILVA-CÁZARES, Macrina Beatriz, GONZÁLEZ-TREVIZO, Cynthia Lizeth and TERRONES-GURROLA, María Cruz del Rocío. Retention capacity of maltodextrin antioxidants in cranberry juice by spray drying process. ECORFAN Journal-Ecuador. 2019. 6-10: 12-20

\footnotetext{
* Correspondence to Author (email: zenaida.saavedra@uaslp.mx)

$\dagger$ Researcher contributing as first author.
} 


\section{Introduction}

Antioxidants are bioactive compounds capable of neutralizing unstable free radicals that cause aging and chronic degenerative diseases, such as cancer, diabetes mellitus, cardio and cerebrovascular diseases, among others (Lee et al., 2015; Masisi et al., 2016; Polanski et al., 2015). From a nutritional point of view, the consumption of foods rich in antioxidants is one of the most effective ways to reduce the risk of chronic diseases.

Cranberries have been recognized for its high content of phenolic and flavonoid compounds, such as quercetin, resveratrol, myricetin and kaempferol (Parada-Caro, 2005). However, the use of this fruit as a source of antioxidants is restricted, as it is a perishable food with a high aqueous content of up to $85 \%$ (Hyun-Chun et al., 2012). In 2014, Mexico obtained a production of 5,529 tons of fresh cranberry (Sagarpa, 2014) of which $50 \%$ was processed in the form of various products, such as juices, nectars, yogurts, jams and semiprepared foods, like powders, syrups and reconstitute concentrates (Skrovankova et al., 2015; Waheeda et al., 2015). Unfortunately, during the processing of the fruit, there are losses of the antioxidant compounds, associated with the heat treatments since the phenolic compounds are heat sensitive at temperatures above $60^{\circ} \mathrm{C}$ (Wang et al., 2009).

The lack of adequate conservation methods that allow lengthening the shelf life, obtaining minimal losses of volatile components (phenolic and flavonoids) and maintaining the nutritional and organoleptic qualities during the processing and storage of the cranberry, has caused losses of 20\% to 50\% (FeippeFernández, 2013; Cano-Chauca et al., 2005). This leads to the search for more appropriate conservation methods. A viable alternative is spray drying, which has been preferred as an economical, flexible process, easy to operate and control, with high drying rates (Silva et al., 2008; Porras-Saavedra et al., 2015) and very short residence times, allowing heat-sensitive products to be dehydrated at relatively high temperatures, retaining some properties of foods such as taste, color, smell and nutrients (Masters, 1991; Mujumdar, 1998). As a result, a powder product is obtained with a longer shelf life and a reduced volume, a useful feature in terms of storage and transport (Cano-Chauca et al., 2005).
However, the difficulty of applying spray drying in products, such as fruit juices, is due to high water and sugar contents, which have a low glass transition temperature $\left(\mathrm{T}_{\mathrm{g}}\right)$ (Van Sleeuwen et al., 2012; Saavedra-Leos et al., 2012; Collares and Kieckbush, 2002; Vanhal and Blond, 1999; Ruan et al., 1999). This causes low yields, operating problems and difficulty in predicting product quality. A practical solution is the use of high molecular weight additives (adjuvants) as carrier agents to modify the properties of the material in order to reduce the problem of sticking during spray drying (Saavedra-Leos et al., 2015; Ceballos -Peñaloza, 2008). The amount of carrier agent used ranges from $20 \%$ to $60 \% \mathrm{w} / \mathrm{v}$ for food dehydration (Masters, 1991).

In spray drying, maltodextrin is used as a carrier agent mainly because of its high molecular weight, low viscosity and glass transition temperature $\left(\mathrm{T}_{\mathrm{g}}\right)$ in a range of 100 to $188{ }^{\circ} \mathrm{C}$, which depends on its dextrose equivalent (DE). This polysaccharide can have a $\mathrm{DE}$ value of 5-40 and depending on it, maltodextrin has different physicochemical and functional properties (Udomrati and Gohtani, 2015; Reineccius, 1991). Based on the above, it can be established that factors such as spray drying temperature and the type and percentage of carrier agent are determinants to improve the performance and quality of powdered juices. It is important to carry out systematic studies based on the use of statistical tools that allow evaluating the effect of these factors, in order to establish the optimal conditions for the processing of fruit juices guaranteeing a good efficiency.

That is why in the present work a design of D-Optimal experiments was used to evaluate four maltodextrins and concentrations of 10 to $30 \% \mathrm{w} / \mathrm{w}$, as well as drying temperatures of 170 to $210{ }^{\circ} \mathrm{C}$, to obtain cranberry juice powder and evaluate the performance and retention capacity of antioxidants.

\section{Methodology}

\section{Spray drying}

Dehydration was carried out in a Mini Spray Dryer B290 (Buchi, Switzerland). The samples were placed in the dryer at room temperature and a volumetric flow of hot air of $35 \mathrm{~m}^{3} / \mathrm{h}$ was used, adjusting the vacuum to $70 \%$ capacity. 
A constant compressed air pressure of 1.5 bar was used. A total of 25 experiments were performed, where a range of inlet temperatures between $170{ }^{\circ} \mathrm{C}$ and $210^{\circ} \mathrm{C}$ was handled, while the output was recorded between $70{ }^{\circ} \mathrm{C}$ and 90 ${ }^{\circ} \mathrm{C}$. As the encapsulating agent, maltodextrin (MD) with different equivalents of dextrose (Mc, M10, M20, M40) was used at different concentrations as specified in Table 1.

\begin{tabular}{|l|l|r|r|r|}
\hline Random & \multicolumn{1}{|c|}{ Run } & \multicolumn{1}{|c|}{ Factor 1 } & \multicolumn{1}{c|}{ Factor 2 } & Factor 3 \\
\hline & & \multicolumn{1}{c|}{$\left.\mathbf{C}^{\circ} \mathbf{C}\right)$} & \multicolumn{1}{c|}{ (g) } & MD* \\
\hline 12 & 1 & 181.297271 & 30 & M40 \\
\hline 22 & 2 & 193.06311 & 30 & M10 \\
\hline 14 & 3 & 193.06311 & 30 & M10 \\
\hline 18 & 4 & 190 & 25.043167 & M20 \\
\hline 5 & 5 & 210 & 30 & MC \\
\hline 11 & 6 & 170 & 10 & M20 \\
\hline 1 & 7 & 170 & 30 & MC \\
\hline 16 & 8 & 175.00002 & 12.5 & MC \\
\hline 19 & 9 & 209.375 & 24.1630577 & M40 \\
\hline 4 & 10 & 210 & 10 & M40 \\
\hline 21 & 11 & 170 & 10 & M40 \\
\hline 17 & 12 & 190 & 19.6296296 & M10 \\
\hline 8 & 13 & 170 & 10 & M40 \\
\hline 23 & 14 & 170 & 10 & M20 \\
\hline 20 & 15 & 210 & 20 & MC \\
\hline 3 & 16 & 170 & 30 & M20 \\
\hline 24 & 17 & 181.297271 & 30 & M40 \\
\hline 2 & 18 & 186.541152 & 10 & M10 \\
\hline 10 & 19 & 170 & 21.6266586 & M10 \\
\hline 7 & 20 & 210 & 10 & M20 \\
\hline 13 & 21 & 189.99939 & 20.0003722 & MC \\
\hline 6 & 22 & 210 & 18.3871388 & M10 \\
\hline 9 & 23 & 210 & 10 & MC \\
\hline 25 & 24 & 170 & 21.6266586 & M10 \\
\hline 15 & 25 & 210 & 30 & M20 \\
\hline & & & & \\
\hline
\end{tabular}

$* \mathrm{MD}=$ maltodextrin

Table 1 Design of experiments for D-Optimal analysis Source: Prepared by the authors

\section{Design of experiments}

A design of D-optimal experiments was used in Minitab 17, to evaluate the effect of the concentration of the carrier agent with different degrees of dextrose and different drying temperatures, in order to establish the optimal conditions for obtaining the best yields of cranberry juice powder. The 3 factors to be analyzed were classified as follows: 1) Temperature (T): 170, 175, 181, 187, 190, 193, 209 and $210{ }^{\circ} \mathrm{C}$; 2) Maltodextrin concentration (C): 10, 12.5, 18, 20, 22, 24, 25 and 30\% w/w; and 3) Type of maltodextrin (MD): Mc, M10, M20, M40.

The response variables were: 1) Yield of dust collected in \% w/w; and 2) Retention of antioxidants from cranberry juice in $\mu \mathrm{g} / \mathrm{mL}$.
The design consisted of 25 experimental runs (Table 1), which were randomly selected in order to determine the response variables for each sample. To draw the contour curve graphs, a numerical assignment was made to the type of maltodextrin factor of $0,10,20$ and 40 for $\mathrm{Mc}$, M10, M20 and M40, respectively. Similarly, an ANOVA analysis was performed to estimate the effect of the factors evaluated on the performance of the powder juice obtained.

\section{Determination of antioxidant content by High Performance Liquid Chromatography (HPLC)}

HPLC was carried out with a Waters chromatographic equipment (Waters Assoc. Milford MA, USA) composed of a Binary pump (HPLC model 1525), an autoinjector (model 717) and a double wavelength absorbance detector (model 2487).

The quantification of resveratrol and quercetin was performed under the following operating conditions: room temperature with a mobile phase of acetonitrile: formic acid $0.01 \%$ $\mathrm{pH} 3.0(70: 30 \mathrm{v} / \mathrm{v})$ at a flow of $1 \mathrm{~mL} / \mathrm{min}$ and a length of $306 \mathrm{~nm}$ wave. Chromatographic separation was carried out on a column of the Agilent C18 brand, (75 x $4.6 \mathrm{~mm}$ ID $3.5 \mu \mathrm{m})$ with an injection volume of $10 \mu \mathrm{L}$. All data was processed with the Empower Pro Version 4.0 program.

The calibration curves were made from stock solutions of resveratrol $(1000 \mu \mathrm{g} / \mathrm{mL})$ and quercetin $(1000 \mu \mathrm{g} / \mathrm{mL})$, prepared in HPLC grade methanol. The dilutions used were $0.01,1$, 5,10 and $20 \mu \mathrm{g} / \mathrm{mL}$, to prepare the six-point calibration curve. All solutions were prepared the same day as their injection.

Approximately $0.5 \mathrm{~g}$ in triplicate were weighed for sample extraction, to which a mixture of $0.01 \%$ acetronitrile and phosphoric acid (50:50 v/v) was added. Subsequently, it was vigorously stirred for 5 minutes and left in a dark place for 24 hours. Finally, the solutions were passed through Acrodisc filters of $0.45 \mu \mathrm{m}$ and were injected into the equipment.

\section{Results}

Table 2 shows the yields of obtaining dried cranberry juice under the different established conditions. 


\begin{tabular}{|c|c|c|c|c|}
\hline MD* & $\begin{array}{c}\text { MD* } \\
\text { Concentration } \\
\text { (\% weight) }\end{array}$ & $\begin{array}{c}\text { Cranberry juice } \\
\text { concentration (\% } \\
\text { weight) }\end{array}$ & $\begin{array}{l}\text { Drying } \\
\text { temperature } \\
\left({ }^{\circ} \mathbf{C}\right)\end{array}$ & $\begin{array}{c}\text { Yield } \\
(\%)\end{array}$ \\
\hline M40 & 30 & 70 & 181 & 2.02 \\
\hline M10 & 30 & 70 & 193 & 9.68 \\
\hline M10 & 30 & 70 & 193 & 11.87 \\
\hline M20 & 25 & 75 & 190 & 2.81 \\
\hline $\mathrm{Mc}$ & 30 & 70 & 210 & 6.74 \\
\hline M20 & 10 & 90 & 170 & 0 \\
\hline $\mathrm{Mc}$ & 30 & 70 & 170 & 6.37 \\
\hline $\mathrm{Mc}$ & 12.5 & 87.5 & 175 & 1.82 \\
\hline M40 & 24 & 76 & 209 & 7.43 \\
\hline M40 & 10 & 90 & 210 & 0 \\
\hline M40 & 10 & 90 & 170 & 0 \\
\hline M10 & 20 & 80 & 190 & 8.15 \\
\hline M40 & 10 & 90 & 170 & 0 \\
\hline M20 & 10 & 90 & 170 & 0 \\
\hline $\mathrm{Mc}$ & 20 & 80 & 210 & 7.68 \\
\hline M20 & 30 & 70 & 170 & 4.23 \\
\hline M40 & 30 & 70 & 181 & 1.25 \\
\hline M10 & 10 & 90 & 187 & 0.12 \\
\hline M10 & 22 & 78 & 170 & 9.48 \\
\hline M20 & 10 & 90 & 210 & 0 \\
\hline $\mathrm{Mc}$ & 20 & 80 & 190 & 7 \\
\hline M10 & 18 & 82 & 210 & 5.45 \\
\hline $\mathrm{Mc}$ & 10 & 90 & 210 & 0 \\
\hline M10 & 22 & 78 & 170 & 8.37 \\
\hline M20 & 30 & 70 & 210 & 3.03 \\
\hline
\end{tabular}

$* \mathrm{MD}=$ maltodextrin

Table 2 Efficiency and drying conditions of maltodextrins Source: Prepared by the authors

The highest yield was obtained by using a $20 \% \mathrm{w} / \mathrm{w}$ concentration of maltodextrin at a process temperature of $210{ }^{\circ} \mathrm{C}$, with a weight yield of $7.68 \%$. When using a concentration of $30 \% \mathrm{w} / \mathrm{w}$ at 210 and $170{ }^{\circ} \mathrm{C}$, a lower yield of $6.74 \%$ and $6.37 \%$, respectively, was obtained.

In the case of a concentration of 12.5 and $10 \% \mathrm{w} / \mathrm{w}$ of maltodextrin, a collapse of the system associated with problems of bonding of the material in the walls of the drying chamber was observed. These results are similar to those reported by Saavedra et al. (2015) when using a $30 \% \mathrm{w} / \mathrm{w}$ concentration of carrier agent; however, there are no similar reports of system collapse when using 20,12.5 and $10 \% \mathrm{w} / \mathrm{w}$ of maltodextrin.

In the case of M10 and based on experiment design, the concentrations handled were: 10, 18, 20, 22 and $30 \% \mathrm{w} / \mathrm{w}$ of carrier. Of the results analyzed in Table 2 , the highest yield was obtained using a concentration of $30 \% \mathrm{w} / \mathrm{w}$ maltodextrin at $193{ }^{\circ} \mathrm{C}$, with a yield of $11.87 \%$. From the duplicate under these same conditions, a yield of $9.68 \%$ was obtained, with a general average of $10.77 \pm 1.5485$. On the other hand, at a concentration of $22 \% \mathrm{w} / \mathrm{w}$ and $170{ }^{\circ} \mathrm{C}$, a yield of $9.48 \%$ and $8.37 \%$ was obtained in duplicate, giving an average of $8.925 \pm 0.7848$.
Likewise, when using a concentration of $20 \% \mathrm{w} / \mathrm{w}$ at $190{ }^{\circ} \mathrm{C}$, a yield of $8.15 \%$ was reached. In the case of a concentration of $18 \%$ $\mathrm{w} / \mathrm{w}$ and a process temperature of $210^{\circ} \mathrm{C}$, a yield of $5.45 \%$ was obtained. And finally, at $10 \% \mathrm{w} / \mathrm{w}$ of carrier agent the system collapsed, so the yield obtained was only $0.12 \%$. These results are consistent with those reported by Caliskan and Dirim (2013), who studied the feasibility of a spray drying process of sumac extract (Rhus coriaria L.) with the addition of maltodextrin DE 10.

They used inlet/outlet temperatures of air of $160 / 80,180 / 90$ and $200 / 100{ }^{\circ} \mathrm{C}$, and adjusted the total solids content of the extract to 10,15 , 20 and $25 \%$ w/w with the addition of maltodextrin DE10. The researchers obtained yields of $70.21 \%, 86.77 \%, 97.45 \%$ and $98.5 \%$ for extracts with 10, 15, 20 and $25 \%$ maltodextrin (ED 10) respectively, which allowed to conclude that increasing the concentration of carrier agent increased the yield of the powder obtained. On the other hand, Nadeem et al. (2011) obtained similar results to those reported in this work when using M10.

These researchers sprayed mountain tea (Sideritis stricta) using maltodextrin DE12 as a carrier at two concentrations ( 3 and $5 \% \mathrm{w} / \mathrm{w}$ ) and three different drying temperatures $\left(145^{\circ} \mathrm{C}, 155\right.$ ${ }^{\circ} \mathrm{C}$ and $165^{\circ} \mathrm{C}$ ). They found that the increase in product performance was related to the concentration of carrier and not to the temperature process, which may be associated with a higher solids content of the feed solution. In this regard, Ameri and Maa (2006) point out that increasing the total solids content of the feed solution is a way to increase the recovery of powder in spray drying operations.

Regarding M20, concentrations of 10, 25 and $30 \% \mathrm{w} / \mathrm{w}$ of maltodextrin were used. When comparing the results in Table 2, it is observed that the highest yield was obtained by using a concentration of $30 \% \mathrm{w} / \mathrm{w}$ at a process temperature of $170{ }^{\circ} \mathrm{C}$, with a weight yield of $4.23 \%$. At this same concentration and at a temperature of $210{ }^{\circ} \mathrm{C}$, a yield of $3.03 \%$ was obtained, while for a concentration of $25 \% \mathrm{w} / \mathrm{w}$ of maltodextrin at a process temperature of 190 ${ }^{\circ} \mathrm{C}$ a yield of $2.81 \%$ was obtained. In the case of a $10 \% \mathrm{w} / \mathrm{w}$ concentration of maltodextrin at temperatures of 170 and $210{ }^{\circ} \mathrm{C}$ respectively, the samples collapsed. 
These results are similar to those reported by Bhusari et al. (2014), who studied the effects of different carrier agents, including DE20 maltodextrin, on the physical and microstructural properties of spray dried tamarind pulp powder. They observed an improvement in product recovery by increasing the concentration of the carrier. This increase in the percentage of powder recovery is attributed to the reduction in the adhesion and deposition of powder particles in the walls of the drying chamber, as well as to the increase in the glass transition temperature resulting from the mixing of the carrier agent and tamarind pulp.

On the other hand, Peng et al., (2013) showed similar results to those obtained in this work; they used maltodextrin DE20 when spray dried purple sweet potato flour with $\mathrm{p} / \mathrm{w}$ percentages of maltodextrin from 10 to $40 \%$, observing a greater increase with a $30 \%$ concentration of maltodextrin. However, they observed that as the percentage of maltodextrin increased from 30 to $40 \%$, there were slight changes in yield, but a significant decrease in the quality of the powder obtained.

Finally, for M40 maltodextrin, concentrations of 10,24 and $30 \% \mathrm{w} / \mathrm{w}$ were used. According to the results of Table 2, it was observed that the highest yield was obtained by using a concentration of $24 \% \mathrm{w} / \mathrm{w}$ at a process temperature of $209{ }^{\circ} \mathrm{C}$, with a value of $7.43 \%$. For a concentration of $30 \% \mathrm{w} / \mathrm{w}$ and a process temperature of $181{ }^{\circ} \mathrm{C}$, a lower yield of $2.02 \%$ and $1.25 \%$ was obtained, with a general average of $1.635 \pm 0.5444$. In the case of a $10 \% \mathrm{w} / \mathrm{w}$ concentration of maltodextrin at temperatures of 170 and $210{ }^{\circ} \mathrm{C}$ respectively, said samples collapsed.

These results are similar to those reported by Saavedra et al., (2015) who analyzed the relationship between the degree of polymerization and the physicochemical properties of 4 samples of maltodextrin with different equivalents of dextrose, including maltodextrin DE40, under a spray drying process. In his research the performance of the product was not studied.
However, they mention that the lowest glass transition $\left(\mathrm{T}_{\mathrm{g}}\right)$ was presented by maltodextrin with a greater degree of dextrose equivalents (M40), so it can be assumed that the lowest yields were obtained when using M40, since the primary effect of the addition of adjuvants such as maltodextrins lies mainly in increasing the $\mathrm{Tg}$ of the system to avoid problems of sticking and collapse in the dryer chamber.

It can be observed in Table 2 that the highest percentage was achieved by using $30 \%$ w/w of M10 at a process temperature of $193{ }^{\circ} \mathrm{C}$. With these results, it can be perceived that the use of the M10 carrier agent in the spray drying process of cranberry juice favors the obtention of higher yields. These results are consistent with those obtained by Saavedra et al., (2015) who proposes the use of M10 as a carrier agent in spray drying of sugar-rich systems such as fruit juices, due to their physical $\left(\mathrm{Tg}=100^{\circ} \mathrm{C}\right.$ and 90 ${ }^{\circ} \mathrm{C}, \mathrm{Td}=$ greater than $190{ }^{\circ} \mathrm{C}$ ) and chemical properties (experimental DE $=1$ and Degree of polymerization $=16$ ).

\section{D-Optimal Analysis}

Of the treatments proposed in the D-optimal design, a yield range of cranberry juice from 0 to $11 \%$ was obtained. From the combination of the three factors evaluated, we prepared the graphs corresponding to the contour curves (Figure 1). To identify the regions associated with the best yields, yield curves greater than $10 \%$ were analyzed, which are presented in an intense green color in Figure 1.

For the drying temperature-concentration ratio of maltodextrin (Figure 1a), there are two optimal regions, the first between $20-23 \%$ maltodextrin and $170-175{ }^{\circ} \mathrm{C}$, and the second at concentrations of $28-30 \%$ maltodextrin in an interval from $190-200^{\circ} \mathrm{C}$. In Figure $1 \mathrm{~b}$ where the contour curves of the drying temperature-type of maltodextrin ratio are shown, the optimal region for M10 is set at temperatures of $170^{\circ}$ and 190 $195^{\circ} \mathrm{C}$.

Finally, for the concentration-type of maltodextrin ratio (Figure 1c) the optimal region corresponds to M10 at a concentration of $30 \%$ maltodextrin. Based on the results obtained from the contour curves, it can be established that M10 maltodextrin is the carrier agent that allows obtaining the best yields at a concentration of $30 \%$ and temperatures between $190-195{ }^{\circ} \mathrm{C}$.

SAAVEDRA-LEOS, María Zenaida, SILVA-CÁZARES, Macrina Beatriz, GONZÁLEZ-TREVIZO, Cynthia Lizeth and TERRONES-GURROLA, María Cruz del Rocío. Retention capacity of maltodextrin antioxidants in cranberry juice by spray drying process. ECORFAN Journal-Ecuador. 2019 


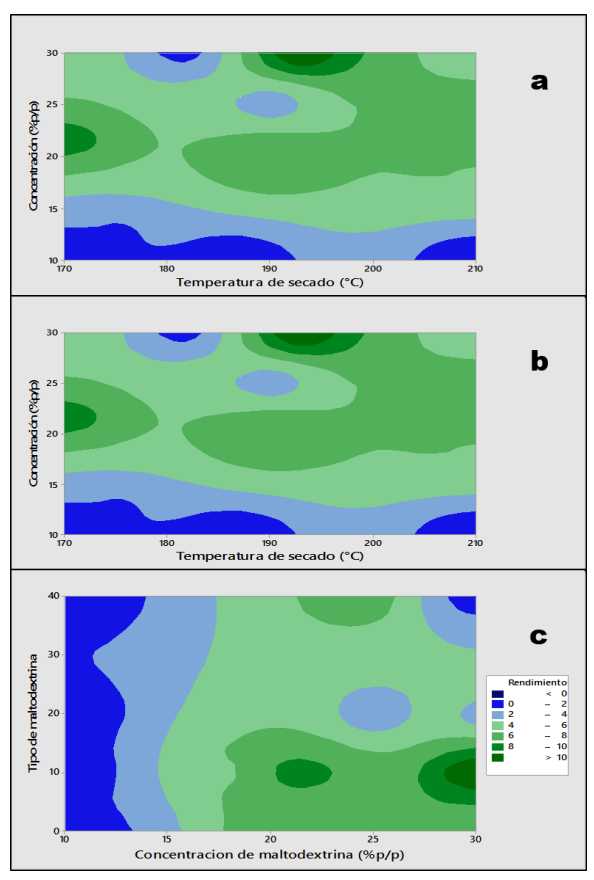

Figure 1 Contour graphs for the relations a) Drying temperature-concentration of maltodextrin, b) Drying temperature-type of maltodextrin, c) Concentration of maltodextrin-type of maltodextrin

Source: Prepared by the authors

Table 3 shows the results of the analysis of variance $(\alpha=0.05)$, where the independent effect is determined. It shows that the concentration and type of MD are the only factors that have a significant effect on the yield of the powdered juice, while the temperature showed no significant effect. Based on these results, it can be concluded that to obtain the best yields the determining factors to consider are the concentration and type of MD.

\begin{tabular}{|l|l|l|l|l|l|}
\hline Source & GL & \multicolumn{1}{|c}{ SC } & \multicolumn{1}{c|}{ MC } & F & p \\
\hline Temperature & 8 & 119.7412 & 14.9676 & 5.854 & 0.248 \\
\hline Concentration & 6 & 190.0694 & 31.6782 & 1.303 & 0.011 \\
\hline Type of MD & 5 & 9.1718 & 1.8344 & 2.578 & 0.000 \\
\hline Error & 3 & 0.6160 & 0.2053 & & \\
\hline Total & 22 & 319.5985 & & & \\
\hline
\end{tabular}

Table 3 Analysis of variance for the performance of cranberry juice powder.

Source: Prepared by the authors

\section{Antioxidant retention}

The results corresponding to the retention capacity of antioxidants in cranberry juice are shown in Table 3. It is observed that the sample AJ-M10 at $30 \%(w / w)$ and $193{ }^{\circ} \mathrm{C}$ was the only sample that managed to retain antioxidants Regarding resveratrol, this varied from 0.662 $\mu \mathrm{g} / \mathrm{mL}$ in cranberry juice to $0.140 \mu \mathrm{g} / \mathrm{g}$ powder with maltodextrin (AJ-Mc).
While for quercetin 3-D-galactoside the content ranged from $0.326 \mu \mathrm{g} / \mathrm{mL}$ in cranberry juice, to $0.093 \mu \mathrm{g} / \mathrm{g}$ powder in the AJ-M10 sample at $30 \%(\mathrm{w} / \mathrm{w})$ at $193{ }^{\circ} \mathrm{C}$. These results coincide with those reported by Robert et al., (2010), who encapsulated bioactive compounds of pomegranate juice and ethanolic extracts with maltodextrin and soy protein isolate by spray drying.

Bakowska-Barczak and Kolodziejczyk (2011) found that inulin was less effective in the encapsulation of blackcurrant polyphenols (Ribes nigrum L.) than maltodextrin. While Santiago-Adame et al. (2015) managed to retain about $60 \%$ of polyphenols by spray drying cinnamon infusions, using maltodextrin as an encapsulating material.

González et al. (2011) evaluated a series of treatments to conserve volatile watermelon juice compounds with spray drying, where they obtained a greater conservation of these compounds by using a mixture of maltodextrin DE10 and gum arabic $1: 1 \mathrm{p} / \mathrm{p}$ and less conservation when using only maltodextrin or only gum arabic as carrier. Likewise, QuirinoLacerda et al. (2016) mention in their work that when performing spray drying of jussara pulp, a higher anthocyanin content was obtained by using mixtures of maltodextrin and inulin as the wall material.

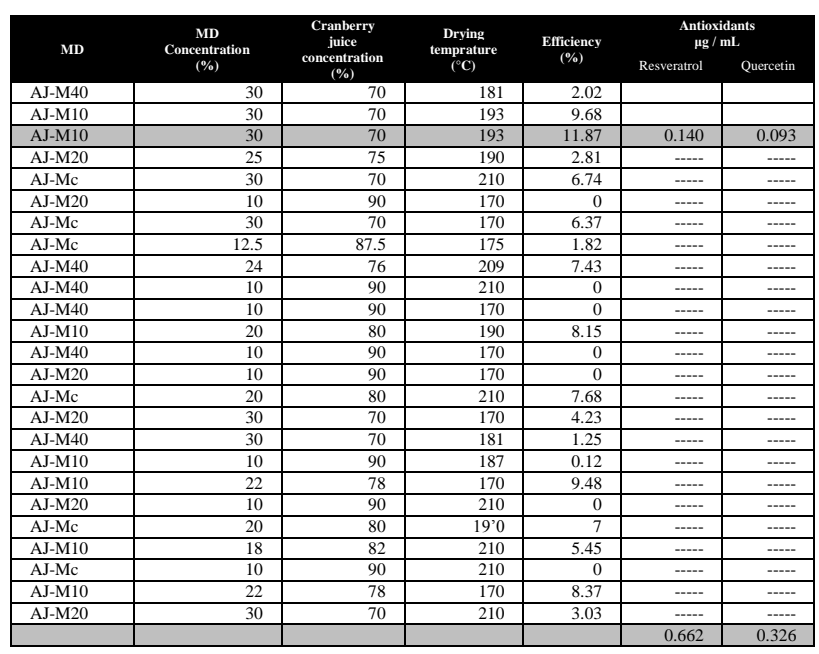

Table 4 Resveratrol and quercetin antioxidant concentration of cranberry juice powder

Source: Prepared by the authors

Although maltodextrin has been one of the most used carrier agents for drying fruit juices, it is evident that it has a limited capacity to retain the antioxidants present in cranberry juice. 
So it would be interesting and a better alternative to use mixtures of maltodextrin with other carrier agents to improve the retention of antioxidants.

\section{Conclusions}

Cranberry juice powder was obtained by using Mc, M10, M20 and M40 at concentrations of 30, 20, 25, 24, 22 and $18 \mathrm{w} / \mathrm{w}$ and a process temperature of: 210, 209, 193, 190, 181 and 175, $170{ }^{\circ} \mathrm{C}$.

The Mc, M10, M20 and M40 systems collapsed when using a concentration of $12.5,10$ $\mathrm{w} / \mathrm{w}$ at a process temperature of 210,175 and $170{ }^{\circ} \mathrm{C}$.

The highest percentage of juice powder was obtained at $30 \% \mathrm{w} / \mathrm{w}$ of M10 at a process temperature of $193{ }^{\circ} \mathrm{C}$, which favored higher yields.

Two optimal process regions are established: a) maltodextrin concentrations at $20-23 \mathrm{w} / \mathrm{w}$ and a range of $170-175{ }^{\circ} \mathrm{C}, \mathrm{b}$ ) concentrations of $28-30 \%$ maltodextrin in a range of $190-200{ }^{\circ} \mathrm{C}$.

The optimal region is established for M10 at temperatures of $170^{\circ}$ and $190-195^{\circ} \mathrm{C}$.

For the concentration-type of maltodextrin ratio it was determined that the optimal region corresponds to M10 at a concentration of $30 \%$ maltodextrin.

Based on the results obtained from the contour curves, it can be established that M10 maltodextrin is the carrier agent that obtains the best yields, it was also the only MD that presented resveratrol and quercetin antioxidant retention in an approximate percentage of $20 \%$ and $30 \%$, respectively.

\section{References}

Ameri, M., Maa, Y. F. (2006). Spray drying of biopharmaceuticals: stability and process considerations. Drying Technology, 24, DOI: 10.1080/03602550600685275.

Bakowska-Barczak, A., Kolodziejczyk, P. (2011). Black currant polyphenols: Their storage stability and microencapsulation. Industrial Crops and Products, 34: 1301-1309.
Barbosa, G. V., Vega, H. (2000). Deshidratacion de alimentos. Acribia, Spain, 1-137 y 165-201.

Bhusari, S. N., Muzaffar, K., Kumar, P. (2014). Effect of carrier agents on physical and microstructural properties of spray dried tamarind pulp powder. Powder technology, 266, 354-364.

Caliskan, G., Dirim, S. N. (2013). The effects of the different drying conditions and the amounts of maltodextrin addition during spray drying of sumac extract. Food and bioproducts processing, 91,539-548

Cano-Chauca, M., Stringheta, P. C., Ramos, A. M., Cal-Vidal, J. (2005). Effect of the carriers on the microstructure of mango powder obtained by spray drying and its functional characterization. Innovative Food Science and Emerging Technologies, 6(4), 420-428.

Ceballos-Peñaloza, A. M. (2008). Estudio comparativo de tres sistemas de secado para la producción de un polvo deshidratado de fruta (tesis de pregrado). Universidad Nacional de Colombia, Manizales, Colombia.

Collares F. P, F. P., Kieckbush, T. G. (2002). Revisão: A Transição Vítrea em Produtos Alimentícios. Brazilian of Food Technology, 117-130.

Feippe-Fernández, M. A. (2013). Tecnologías para aumentar la eficiencia en cosecha. Programa Nacional de Investigación Producción Frutícola, 203, 37-50.

González, M. J., Adhikari, K., Sancho-Madriz, M. F. (2011). Sensory characteristics of peachflavored yogurt drinks containing prebiotics and synbiotics. LWT-Food Science and Technology, $44,158-163$.

Hyun-Chun, H., Sung-Kim, M., Sook-Chung, K., Won, M., Bin-Song, K. (2012). Dehydration of blueberries using maltodextrin and the physicochemical properties of dried blueberries. Hor Environmental Biotechnology 53(6), 565570 .

Lee, L., Choi, E.-J., Kim, C.-H., Sung, J., Kim, Y., Seo, D., Park, J. (2015). Contribution of flavonoids to the antioxidant properties of common and tartary buckwheat. Journal of Cereal Science, 68, 181-186. DOI: 10.1016/j.jcs.2015.07.005

SAAVEDRA-LEOS, María Zenaida, SILVA-CÁZARES, Macrina Beatriz, GONZÁLEZ-TREVIZO, Cynthia Lizeth and TERRONES-GURROLA, María Cruz del Rocío. Retention capacity of maltodextrin antioxidants in cranberry juice by spray drying process. ECORFAN Journal-Ecuador. 2019 
Masisi, K., Beta, T., \& Moghadasian, M. H. (2016). Antioxidant properties of diverse cereal grains: A review on in vitro and in vivo studies. Food Chemistry 196:90-97. DOI: 10.1016/j.foodchem.2015.09.021

Masters, K. (1991). Spray Drying Handbook, $5^{\text {a }}$ Edition. Longman Group limited, UK.

Mujumdar. A. S. (1998). Innovation in drying. Trends in Heat Mass and Momentum Transfer, 4.

Nadeem, H. Ş., Torun, M., \& Özdemir, F. (2011). Spray drying of the mountain tea (Sideritis stricta) water extract by using different hydrocolloid carriers. LWT-Food Science and Technology, 44(7), 1626-1635.

Parada-Caro, E.J. (2005). Caracterización del aceite y la fibra dietética obtenidos a partir de semilla de arándano Vaccinium corymbosum L. (tesis de pregrado). Universidad Austral de Chile, Valdivia, Chile.

Peng, Z., Li, J., Guan, Y., \& Zhao, G. (2013). Effect of carriers on physicochemical properties, antioxidant activities and biological components of spray-dried purple sweet potato flours. $L W T$ Food Science and Technology, 51(1), 348-355.

Polanski, J. F., Soares, A. D., \& de Mendonça Cruz, O. L. (2015). Antioxidant therapy in the elderly with tinnitus. Brazilian Journal of Otorhinolaryngology, 82(3):269-274. DOI: 10.1016/j.bjorl.2015.04.016

Porras-Saavedra, J., Palacios-González, E., Lartundo-Rojas, L., Garibay-Febles, V., YáñezFernández, J., Hernández-Sánchez, H., ... Alamilla-Beltrán, L. (2015). Microstructural properties and distribution of components in microparticles obtained by spray-drying. Journal of Food Engineering, 152, 105-112. DOI: 10.1016/j.jfoodeng.2014.11.014.1236.

Quirino-Lacerda, E. C., de Araújo-Calado, V. M., Monteiroc, M, Finotelli, P. V., GuedesTorres, A., Perronea, D. (2016). Starch, inulin and maltodextrin as encapsulating agents affect the quality and stability of jussara pulp microparticles. Carbohydrate Polymers, 151, 500-510.

Reineccius, G. (1991). Carbohydrates for flavor encapsulation. Food Technology, 45(3):144149.
Renaud, S. D., de Lorgeril, M. (1992). Wine, alcohol, platelets, and the French paradox for coronary heart disease. The Lancet, 339(8808), 1523-1526.

Robert, P., T. Gorena, N. Romero, E. Sepulveda, J. Chávez and C. Saenz. (2010). Encapsulation of polyphenols and anthocyanins from pomegranate (Punica granatum) by spray drying. International Journal of Food Science \& Technology, 45:1386-1394.

Ruan, R., Long, Z., Chen, P., Huang, V., Almaer, S., Taub, I. (1999). Pulse NMR Study of Glass Transition in Maltodextrin. Introduction, 64(1), 6-9.

Saavedra-Leos, M. Z., Alvarez-Salas, C., Esneider-Alcalá, M. a., Toxqui-Terán, a., PérezGarcía, S. a., Ruiz-Cabrera, M. a. (2012). Towards an improved calorimetric methodology for glass transition temperature determination in amorphous sugars. CyTA - Journal of Food, 10(4), 258-267. DOI: $10.1080 / 19476337.2011 .639960$

Saavedra-Leos, Z., Leyva-Porras, C., AraujoDíaz, S. B., Toxqui-Teran, A., Borrás-Enríquez, A. J. (2015). Technological application of maltodextrins according to the degree of polymerization. Molecules, 20 (12), 2106721081. DOI: 10.3390/molecules201219746

Sagarpa. (2014). No Title. In Sagarpa 2014. Website:

http://www.sagarpa.gob.mx/saladeprensa/2012/ Paginas/2014B495.aspx

Santiago Adame, R., Medina Torres, L., Gallegos Infantes, J. A., Calderas, F., González Laredo, R. F., Rocha Guzmán, N. E., Ochoa Martínez L. A., Bernad Bernad, M.J. (2015). Spray drying-microencapsulation of cinnamon infusions (Cinnamomum zeylanicum) with maltodextrin, LWT - Food science and Technology. DOI: 10.1016/j.lwt.2015.06.020.

Silva, C. L., Noronha, M. N. de, \& Morim, A. (2008). Experiments in Unit Operations and Processing of Foods. In P. Margarida, Vieira, Ho (Ed.), Experiments in Unit Operations and Processing of Foods (pp. 77-80). Springer US. DOI: 10.1007/978-0-387-68642-4_10 
Skrovankova, S., Sumczynski, D., Mlcek, J., Jurikova, T., Sochor, J. (2015). Bioactive compounds and antioxidant activity in different types of berries. International Journal of Molecular Sciences. DOI: 10.3390/ijms 161024673

Udomrati, S., y Gohtani, S., (2015). Tapioca maltodextrin fatty acid ester as a potential stabilizer for Tween 80-stabilized oil-in-water emulsions. Food Hydrocolloids, 44:23-31.

Van Sleeuwen, R. M. T., Zhang, S., \& Normand, V. (2012). Spatial glass transition temperature variations in polymer glass: application to a maltodextrin-water system. Biomacromolecules, 13(3), 787-97. DOI: 10.1021/bm201708w

Vanhal, I., \& Blond, G. (1999). Impact of melting conditions of sucrose on its glass transition temperature. Journal of agricultural and food chemistry, 47(10), 4285-4290.

Waheeda Mohideen Fathima, Mis Solval Kevin, Li Juan, Zhang Jie, Chouljenko Alexander, Chotiko Arranee, D. Prudente Alfredo, Bankston J. David, Sathivel Subramaniam (2005). Effect of continuous ultra-sonication on microbial counts and physico-chemical properties of blueberry (Vaccinium corymbosum) juice. Food Science and Technology 60: 563-570.

Wang, S. Y., Chen C.T., y Wang, C. Y. (2009). The influence of light and maturity on fruit quality and flavonoid content of red raspberries. Food Chemistry 112, 676-684

Udomrati, S., y Gohtani, S., (2015). Tapioca maltodextrin fatty acid ester as a potential stabilizer for Tween 80-stabilized oil-in-water emulsions. Food Hydrocolloids 44:23-31.

Van Sleeuwen, R. M. T., Zhang, S., \& Normand, V. (2012). Spatial glass transition temperature variations in polymer glass: application to a maltodextrin-water system. Biomacromolecules, 13(3), 787-97. http://doi.org/10.1021/bm201708w

Vanhal, I., \& Blond, G. (1999). Impact of melting conditions of sucrose on its glass transition temperature. Journal of agricultural and food chemistry, 47(10), 4285-4290.
Waheeda Mohideen Fathima, Mis Solval Kevin, Li Juan, Zhang Jie, Chouljenko Alexander, Chotiko Arranee, D. Prudente Alfredo, Bankston J. David, Sathivel Subramaniam (2005). Effect of continuous ultra-sonication on microbial counts and physico-chemical properties of blueberry (Vaccinium corymbosum) juice. Food Science and Technology 60: 563-570.

Wang, S. Y., Chen C.T., y Wang, C. Y. (2009). The influence of light and maturity on fruit quality and flavonoid content of red raspberries. Food Chemistry 112, 676-684 